\title{
22
}

\section{Touring 'Real Life'? Authenticity and Village-based Tourism in the Trobriand Islands of Papua New Guinea}

\author{
Michelle MacCarthy
}

\section{Introduction}

Tina, ${ }^{1}$ a striking young woman of Iranian heritage, travelled on her own from Victoria, Australia, to spend two months in the islands of Milne Bay Province, Papua New Guinea (PNG), with one of those months in the Trobriand Islands. When I spoke with her at length, Tina had been in the Trobriands for about a week and a half. She had stayed in the beachside village of Kaibola for a few days, and then travelled to Tauwema village on Kaileuna Island before returning to the largest island, Kiriwina. Tina organised village stays on the ground by asking around at the guest lodge and in the government station of Losuia. I spoke with Tina outside the small, local bush-materials house she was renting for a few days in Karidakula, the hamlet just

1 All participants were given the option, when briefed about my research and offered a Participant Information Sheet (PIS), to indicate their preference for my using their real name or a pseudonym. I have respected their wishes, but do not indicate here in which cases a pseudonym is used. 
next to Butia Lodge, ${ }^{2}$ where she had just taken a 'bucket shower' in a temporary enclosure built for the purpose. The lodge, a wellestablished guest house with a generator, beds (as opposed to the mat on the floor on which Tina would have slept), and a kitchen stocked with imported foods, was no more than a few hundred metres away, but staying with a local family in each place was appealing to Tina, who preferred to 'rough it', as she put it, and make her money stretch to allow a longer visit.

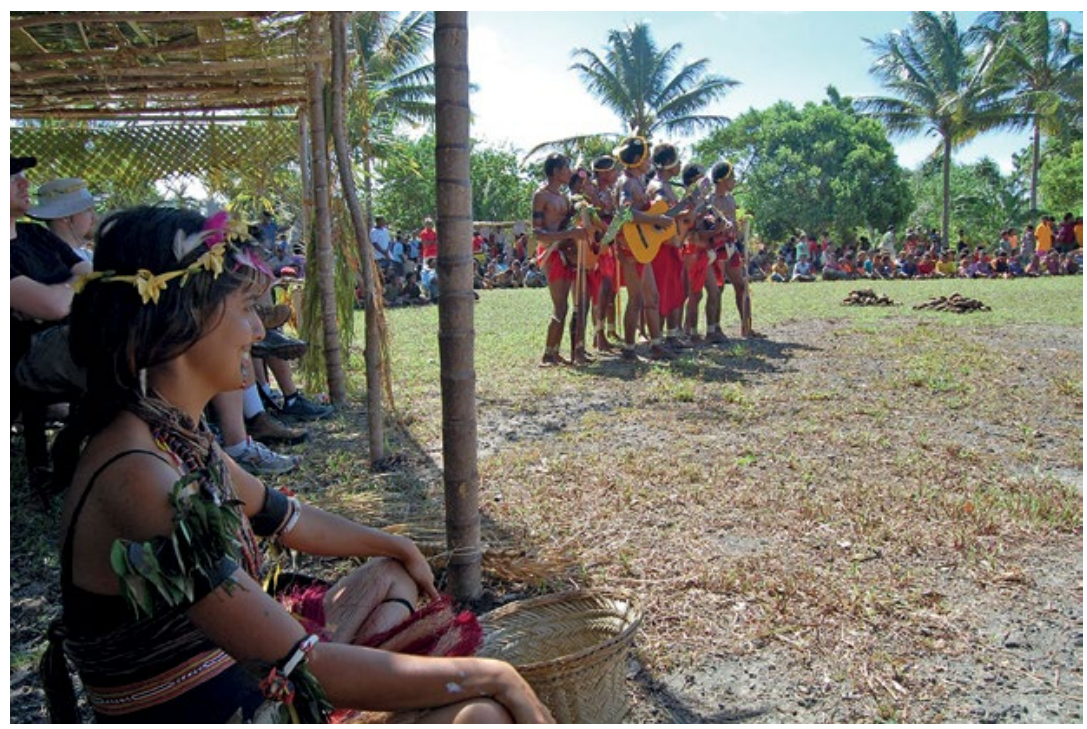

Figure 109. Tina, wearing Trobriand dress, enjoying a performance at Karidakula (grounds of Butia Lodge).

Source. Photographed by Michelle MacCarthy, 11 July 2009.

When I asked Tina why she chose to come to the Trobriands, she told me she felt 'an affinity with the culture', which she was familiar with as she had taken some anthropology courses in university and reads 'lots of books on ceremony and ritual in PNG; I' $m$ really interested in myths and legends. It has always fascinated me.' She also has a fascination, she noted, with 'living spaces - how people arrange themselves socially'. Tina told me she has travelled at least once a year since she

2 Butia Lodge is one of two established guest houses on Kiriwina, offering basic but comfortable accommodation. Amenities include generators to provide electric fans and even air conditioning, full meal service with a combination of local and imported foods, and a bar. Both, however, are locally owned and operated and in no way reflect a 'resort'-type atmosphere. 
was 16, usually on her own for about two months at a time. She had found her experience in PNG thus far safe and easy. She observed that because she stayed in the villages, people were protective, almost treating her like family. 'Here, you'll never feel alone. People worry for you. They're very curious. But I feel so welcome.'

Tina expressed some concern about 'old practises dying out', but says she sees now an interesting melding of Christianity and traditional culture: 'I think it's still a strong culture-you see new influences woven into the old culture. ${ }^{4}$ As her visit coincided with the yam harvest, she was pleased to have seen people carrying yams and stacking them in a heap in the village next to where she stayed in Tauwema, noting the 'visual appeal' of the process. On Kiriwina Island, Tina's experience was also embodied, as she was dressed by her hosts in Trobriand attire to attend the yam harvest festivities carried out during her visit. Tina brought up the issue of authenticity in the course of our discussion, stating that in Thailand, for example, she felt 'sold to'; that everything was about money, and there was little sense that what she was seeing and doing was authentic, which she felt 'devalues the experience - the way you process it, as a traveller'. This word choice, like that of most other tourists I met while in the Trobriands, was deliberate; very few of them would ever refer to themselves as a 'tourist'. While she rinsed out a few pieces of clothing in a basin of water, and wrung them out before hanging them on the line to dry, she continued, 'Things just aren't charged with the same power when they're programmed. You want to feel like you're sharing or witnessing someone's natural practice, not [that it is being done] for your enjoyment. You want them to enjoy it, too.' She told me about having witnessed a School Cultural Day, which was organised 'not for me- for the community. That was nice to see. ${ }^{5}$

While most visitors to the Trobriand Islands do not stay as long as Tina did, nor do they engage as directly with local hosts, her comments reflect the sentiments of most travellers - whether visiting for a few days or a few weeks, travelling independently or on a group tour. The importance of having an authentic personal experience, in a place with authentic cultural others doing authentically cultural things 
(as the visitor perceives it), emerged through my nearly 22 months of fieldwork with residents of and tourists to the Trobriand Islands as of paramount importance to the ways in which visitors assess, understand and narrate their own experiences of intercultural encounters. ${ }^{6}$ Visiting a village, whether on a day excursion or for an overnight stay, is seen by most travellers as an opportunity to see and, ideally, take part in 'life as it is really lived'. Such notions are reinforced by tour operators and travel literature, in which the idea of a consumable authentic other is reified. Take, for example, the following excerpt from the brochure of an adventure tourism company based in North America and aimed at 'small group exotic adventures for travellers 50 plus':

We meet and learn about some of the tribal people of this land including the Asaro Mudmen, the Wahgi, the Simbu, the Kaguel and the fascinating Trobriand Islanders. Our adventure includes many village visits so that we can really meet the people and experience their way of life. ${ }^{7}$

While my fieldwork examined tourism from the perspectives of both resident Trobrianders and tourists, ${ }^{8}$ I here focus only on the tourists' understanding of, and construction of, an authentic cultural experience in the context of extended village stays. My research indicated that the demographic most likely to engage in village stays of more than a night or two are young (usually, but not exclusively, in their 20s and 30s), independent (that is, not on an organised group tour), and well travelled (often with extensive experience in other less-developed countries). In this chapter, I examine the case of what I refer to as 'unperformance' - village visits in which visitors seek authenticity through experiencing the day-to-day activities of island residents, as against formalised touristic performances or events. I wish to demonstrate how the lack of formal tourist infrastructure,

6 My primary doctoral fieldwork was carried out for 18 months in 2009-2010, facilitated by a Wenner Gren Doctoral Dissertation Fieldwork Grant and the Faculty of Arts at the University of Auckland. A supplemental four months of fieldwork in 2013 was supported by the Gender and Pentecostalism project headed by Annelin Eriksen at the University of Bergen, which was focused on new topics but also permitted follow-up to the initial research.

7 'Papua New Guinea - Adventure Travel For 50 Plus', 2016, Eldertreks.Com.

8 Michelle MacCarthy, 2012, “'Before it gets spoiled by tourists": Constructing authenticity in the Trobriand Islands of Papua New Guinea', PhD thesis, Department of Anthropology, University of Auckland; Michelle MacCarthy, 2016, Making the Modern Primitive: Cultural Tourism in the Trobriand Islands, Honolulu: University of Hawai'i Press. 
the dearth of other tourists, and the opportunities to engage directly with local residents offers an experience interpreted by visitors as more meaningful than those experienced by their peers who travel to more developed touristic destinations. I argue that the grassroots nature of tourism in places lacking 'development' (infrastructure and resources not only for the comfort of tourists, but also reflecting the subsistencebased economy and lack of basic services for the resident population) contributes to a romanticisation of the exotic other and a sense of 'Paradise Lost' in their own societies, and creates an ambiguous distinction between performances orchestrated for the entertainment of visitors, and the quotidian events of daily life in the village. This, I contend, leads to a heightened sense of authenticity, both in terms of their personal experiences in the intercultural interaction, and their objective sense of the authenticity of the people they visit. At the same time, however, the tourist of course knows that he or she is not family, and that various comforts and provisions are made, even in the village, on their behalf. There is an inherent tension in the desire to experience 'real life', and the paradox created by the presence of the visitor.

\section{Unperformance}

Most existing cultural tourism research has examined places with a fairly formally established tourism infrastructure, focusing on ethnographic theme parks or 'culture villages'; ${ }^{9}$ dance festivals or floor shows at hotels and resorts featuring 'traditional' dance, ${ }^{10}$

9 For example, Edward M. Bruner (ed.), 2005, Culture on Tour: Ethnographies of Travel, Chicago: University of Chicago Press; Gerhard Schutte, 2003, "Tourists and tribes in the "new" South Africa', Ethnohistory 50(3): 473-87; Nick Stanley, 1998, Being Ourselves for You: The Global Display of Cultures, London: Middlesex University Press.

10 For example, Kalissa Alexeyeff, 2009, Dancing from the Heart: Movement, Gender, and Cook Islands Globalization, Honolulu: University of Hawai'i Press; Aurélie Condevaux, 2009, 'Māori culture on stage: Authenticity and identity in tourist interactions', Anthropological Forum 19(2): 143-61; Yvonne Payne Daniel, 1996, 'Tourism dance performances: Authenticity and creativity', Annals of Tourism Research 23(4): 780-97; Adrienne Kaeppler, 1988, 'Pacific festivals and the promotion of identity, politics, and tourism', in Come Mek Me Hol'Yu Han': The Impact of Tourism on Traditional Music, ed. Adrienne Kaeppler and Olive Lewin, pp. 12-38, Kingston, Jamaica: Jamaica Memory Bank. 
or the proliferation of 'tourist art'. ${ }^{11}$ In these cases, there is a clear separation between performer/producer and audience/consumer, thus reinforcing a sense of the event as 'staged' for both performers and audiences. ${ }^{12}$ In the Trobriands, conversely, tourism is highly informal, and such barriers are not clearly established; the fuzziness resulting from this more 'organic' kind of tourism breaks down the separation between performer and audience. This has significant implications for how the experience is conceived, as the following discussion seeks to illustrate.

There are, in fact, few ethnographic examinations of the phenomenon of the village stay. Village stays as an intercultural phenomenon offer an important window into how travellers and the residents of places promoted as exotic and even 'primitive' interact in the sphere of tourism, as they are based on a more intimate interaction than most touristic visits generally provide. Barbara Kirshenblatt-Gimblett, in her examination of museum displays, notes how exhibitions (and, I would argue, experiences in cultural tourism) often 'force us to make comparisons that pierce the membrane of our own quotidian world, allowing us for a brief moment to be spectacles of ourselves, an effect that is also experienced by those on display'. ${ }^{13}$ This 'propels the fascination with penetrating the life space of others, getting inside, burrowing deep into the most intimate places, whether the interiors

11 For example, Nelson H.H. Graburn (ed.), 1976, Ethnic and Tourist Arts: Cultural Expressions from the Fourth World, Berkeley: University of California Press; Nelson H.H. Graburn, 1984, 'The evolution of tourist arts', Annals of Tourism Research 11(3): 393-419; Nelson H.H. Graburn, 1999, 'Epilogue: Ethnic and tourist arts revisited', in Unpacking Culture: Art and Commodity in the Colonial and Postcolonial Worlds, ed. Ruth B. Phillips and Christopher B. Steiner, pp. 335-54, Berkeley: University of California Press; Eric Kline Silverman, 1999, 'Tourist art as the crafting of identity in the Sepik River (Papua New Guinea)', in Unpacking Culture: Art and Commodity in Colonial and Postcolonial Worlds, ed. Ruth B. Phillips and Christopher B. Steiner, pp. 51-66, Berkeley: University of California Press; Eric Kline Silverman, 2004, 'Cannibalizing, commodifying, or creating culture? Power and art in Sepik River tourism', in Globalization and Culture Change in the Pacific Islands, ed. Victoria S. Lockwood, pp. 339-57, Upper Saddle River, NJ: Pearson Prentice Hall; Christopher B. Steiner, 1999, 'Authenticity, repetition, and the aesthetics of seriality: The work of tourist art in the age of mechanical reproduction', in Unpacking Culture: Art and Commodity in Colonial and Postcolonial Worlds, ed. Ruth B. Phillips and Christopher B. Steiner, pp. 87-103, Berkeley: University of California Press.

12 Erik Cohen, 1988, 'Authenticity and commoditization in tourism', Annals of Tourism Research 15(3): 371-86; Dean MacCannell, 1973, 'Staged authenticity: Arrangements of social space in tourist settings', American Journal of Sociology 79(3): 589-603.

13 Barbara Kirshenblatt-Gimblett, 1998, Destination Culture: Tourism, Museums, and Heritage, Berkeley: University of California Press, p. 48. 
of lives or the innermost recesses of bodies'. ${ }^{14}$ Examining village stays demonstrates the ways in which such intimacy, whether real or perceived, is both internalised and externalised by visitors.

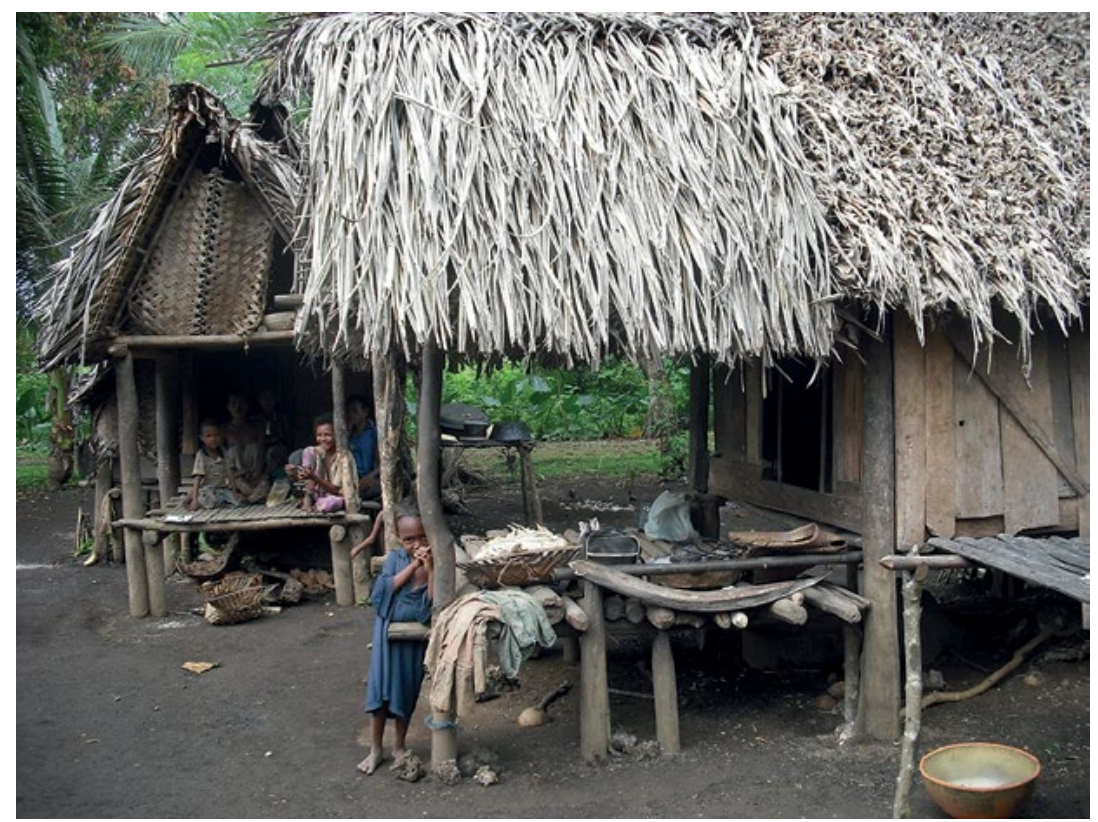

Figure 110. Trobriand village. Wekuku hamlet, Yalumgwa.

Source. Photographed by Michelle MacCarthy, 21 May 2010.

\section{Authenticity in tourism research}

Before I continue with my argument, a few words on definitions and theoretical orientations are necessary regarding the concept of authenticity as both an analytical concept employed by academics and as a trope employed by non-academics. It is important that the reader does not take my approach to be purporting a culturalist agenda, nor validating a reification of authenticity as an essentialist ideal. My interest, rather, is in the way the concept is employed in discourses surrounding tourism, and to what ends. 
Authenticity came to the fore as a key issue in tourism as a result of the publication of Dean MacCannell's groundbreaking work, The Tourist. ${ }^{15}$ For MacCannell, the quest for authenticity is the primary motivating factor for tourists, who are so alienated by the modern condition that they embark on touristic adventures with a sense of longing for what has been lost in 'simpler' times. MacCannell sees tourism as a ritual that attempts to combat the contradictory, fragmented, and ultimately unsatisfying state of modern society. ${ }^{16} \mathrm{He}$ argues that the quest for authenticity is doomed to failure, because the search itself compromises the authenticity of the object or experience, assumed to have been previously pristine and untouched. ${ }^{17}$ Although MacCannell's thesis has been the subject of much debate, it remains a milestone in the study of tourism as a subject of serious academic inquiry. A problem with MacCannell's approach, however, is that he conflates analytical and lay understandings of the term.

In much of the tourism literature, scholars' use of the concept of authenticity is implicitly objectivist, assuming that there is some essential quality or attribute that makes an entity authentic. ${ }^{18}$ This assumption of a true, authentic original presents some methodological and philosophical problems, as many critics have pointed out. ${ }^{19}$ For example, how is the pure, unadulterated, authentic original defined when culture, as we know, is dynamic and constantly renegotiated? This idea of a truly authentic object/ritual/culture is inherently flawed, as every anthropologist knows, in that cultures are not, and have never been, static, unchanging entities. Tourists' understanding of the dynamic nature of cultural processes vary, but most cultural tourists, at least as reflected in the dozens of conversations I had with visitors to the Trobriand Islands, implicitly or

15 Dean MacCannell, 1976, The Tourist: A New Theory of the Leisure Class, New York Schocken Books.

16 MacCannell, The Tourist, p. 13.

17 See also, Bruner, 2005, Culture on Tour, p. 162; Cohen, 'Authenticity and commoditization in tourism', pp. 272-73; John Taylor, 2001, 'Authenticity and sincerity in tourism', Annals of Tourism Research 28(1): 7-26, pp. 11-15.

18 Bruner, 2005, Culture on Tour, p. 163; Tazim Jamal and Steve Hill, 2002, 'The home and the world: (Post)touristic spaces of (in)authenticity?' in The Tourist as a Metaphor of the Social World, ed. Graham M.S. Dann, pp. 77-108, Wallingford, Oxon: CABI Publishing, p. 79.

19 For example, Edward M. Bruner, 1994, 'Abraham Lincoln as authentic reproduction: A critique of postmodernism', American Anthropologist 96(2): 397-415; Bruner, Culture on Tour; Cohen, 'Authenticity and commoditization in tourism'; Jamal and Hill, 'The home and the world'; Kjell Olsen, 2002, 'Authenticity as a concept in tourism research', Tourist Studies 2(2): 159-82. 
explicitly make reference to some tradition-bound, inherent quality of continuity with the past that, to them, signifies an authentic example of 'primitives' in the modern era.

Rather than thinking about authenticity as an analytical concept in objectivist or absolutist terms, I employ a constructivist understanding of the term. Constructivist authenticity takes as its premise the significance of the ways in which people define, recognise and identify a given entity as authentic, even if it is in some way a contrivance, copy, or simulacrum. ${ }^{20}$ In this conceptualisation, authenticity is the result of social construction, rather than an objectively measurable quality of an object/event. Thus, things appear authentic not because of some inherent quality of the object, event, or 'culture', but because they are constructed as such in terms of points of view, beliefs, discourses, perspectives, or powers; authenticity is relative, negotiable, contextual, symbolic and ideological. ${ }^{21}$ Authenticity is thus a projection of tourists' beliefs, expectations, stereotyped images, and desires. I find the constructivist view useful as it begins to bridge the gap between analytical approaches and lay uses of the term, recognising that people's ideas about authenticity are more important than trying to discern whether a given site, sight, performance, or object is or is not authentic. In my discussion of village-based tourism, my focus is to understand how tourists' conceptualisation of authenticity (and sometimes essentialised ideas of the exotic cultural other) influences their interpretations of their experiences, the cultural other with whom they engage, and ultimately themselves. Both material and semiotic elements are interpreted and reinterpreted in myriad ways to make meaning, and ideas about culture, tradition, and authenticity are points of reference for constructing meaning in the context of cultural tourism.

As an alternative way of conceiving of authenticity, Wang has proposed 'existential authenticity', ${ }^{22}$ This is taken to be experienceoriented, and concerns the tourists' personal sense of authenticity

20 Bruner, 'Abraham Lincoln as authentic reproduction'; Bruner, Culture on Tour; Jamal and Hill, 'The home and the world'; Siân Jones, 2010, 'Negotiating authentic objects and authentic selves', Journal of Material Culture 15(2): 181-203; Richard A. Peterson, 2005, 'In search of authenticity', Journal of Management Studies 42(5): 1083-98; Ning Wang, 1999, 'Rethinking authenticity in tourism experience', Annals of Tourism Research 26(2): 349-70.

21 Edward M. Bruner, 1991, 'Transformation of self in tourism', Annals of Tourism Research 18(2): 238-50; Bruner, 'Abraham Lincoln as authentic reproduction'.

22 Wang, 'Rethinking authenticity in tourism experience'. 
of the self, achieved through experiencing the liminal process of tourism. ${ }^{23}$ As such, like constructivist authenticity, it bears no relation to the (real or perceived) authenticity of objects or events. Wang suggests that constructivist authenticity is object-oriented, rather than experience-oriented, but I interpret constructivist authenticity as more encompassing. I contend that an experiential or even existential understanding of authenticity can easily be incorporated into the constructivist approach, to ensure that the analytical understanding of the authenticity encompasses both an outward-looking and an inward-looking orientation. A constructivist analytical standpoint that allows for the importance of both the ways in which tourists perceive cultural difference, and the ways in which they perceive their own experience in the village as embodied and sensory (existential authenticity), is a particularly useful conceptual tool for analysing tourist-local interactions in places conceived of in the popular imagination as dramatically and quintessentially other.

\section{'Social distance' in tourism}

In most destinations, the infrastructure for visiting 'a culture', as the tour operators and many travellers would have it, is much more formally developed than is the case in PNG. In northern Thailand, for example, hill treks are well established with set routes, trained local guides, and the opportunity to stay with 'real villagers' overnight and offering a series of well-orchestrated examples of Akha, Hmong and/or Karen ways of life. In Lake Titicaca in Peru, groups of foreign tourists visit villages on the reed island of Amantani and, day after day, designated host families welcome tourists, provide the opportunity to wear local dress, and attend a dance in the local community hall, all clearly staged for tourists but designed to provide the visitor not only with a sense of what authentic village life is like, but an embodied experience of dressing up like an Amatani Islander and eating dinner with a local family in their home. Such experiences are clearly a thing apart from floor shows and other formal cultural performances, which are literally presented on a stage with a distinct separation between (local) performer and (foreign) audience. And yet, they are also a performance, and while travellers might willingly suspend disbelief in order to feel that what they are experiencing 
is authentic in some way that is meaningful to them, most tourists on some level likely recognise that these exact patterns are repeated daily, that one visits with a large group of other tourists, that the choreography of the interactions is designed to be seamless, and that the actual interactions with individual local hosts are relatively brief. While these experiences can certainly have meaning for tourists, and can offer insight into another way of life and a space for self-reflection, I argue that a place like the Trobriand Islands is conceived, by those relatively few tourists who travel there, as something quite apart from such established tourist experiences. This is especially so for those travellers who stay in a village for part or all of their visits.

A village stay, in practical terms, offers the traveller the opportunity to stay in a local house constructed of bush materials, and to 'rough it' by sleeping on a mat or thin mattress on the floor, using only a lamp for light. They will eat 'local' food (though, in practice, are likely to have more protein and store-bought food than most locals normally eat), and may have the opportunity to engage in activities like visiting the gardens, going fishing, attending a community sporting match or feast, and simply observing the daily rhythm of life for island residents. They can thus feel that they have taken part and seen an aspect of community life that sets them apart from those who visit by cruise ship or group tour.

In the Trobriands, as with many other cultural tourism localities, visiting a village is seen by tourists as a way of interacting with representatives of the cultural other in a more meaningful and 'real' way, though, of course, much of what is exposed to the tourist gaze is orchestrated by tour operators, foreign or local guides, or the village residents themselves. ${ }^{24}$ These interactions, too, are a kind of performance. But again, what matters most to tourists is not 'reality', as such, but their own construction of it. Those who, like Tina, organise their own visits - without the intervention or assistance of a tour operator or an accompanying guide, and the hefty payments that are associated with such infrastructure - are most likely to interpret their experiences as truly 'authentic'. I suggest that there is something here akin to Marshall Sahlins' thesis regarding social distance. ${ }^{25}$

24 MacCannell, 'Staged authenticity'; see also Christian S. Hammons, 2015, 'Shamanism, tourism, and secrecy: Revelation and concealment in Siberut, Western Indonesia', Ethnos: Journal of Anthropology 80(4): 548-67.

25 Marshall Sahlins, 1972, 'On the sociology of primitive exchange', in Stone Age Economics, ed. Marshall Sahlins, pp. 185-276, London: Tavistock. 
Sahlins, of course, is addressing general rules governing the kinds of reciprocity between people in very close, kin-based relationships as opposed to those who do not share close social ties. In this case, I suggest that the degree to which tourists conceive of their own experience, and the qualities of the tourism 'products' they consume (including a village stay and the people who provide such services) as authentic is positively correlated with the (perceived, whether or not real in objective terms) 'closeness' of their encounter. This is reflected in terms of both embodied experience (staying in a local house, eating local food, wearing local dress, participating in a local game) and the almost voyeuristic satisfaction of seeing something intended for a local audience rather than a tourist audience, like the school cultural day mentioned by Tina in the opening vignette to this chapter, or attending a village mortuary feast. The absence of other tourists can also lend a sense of closeness not afforded in more established destinations. Let me here provide a few ethnographic examples to demonstrate the ways in which this is conceived by tourists themselves.

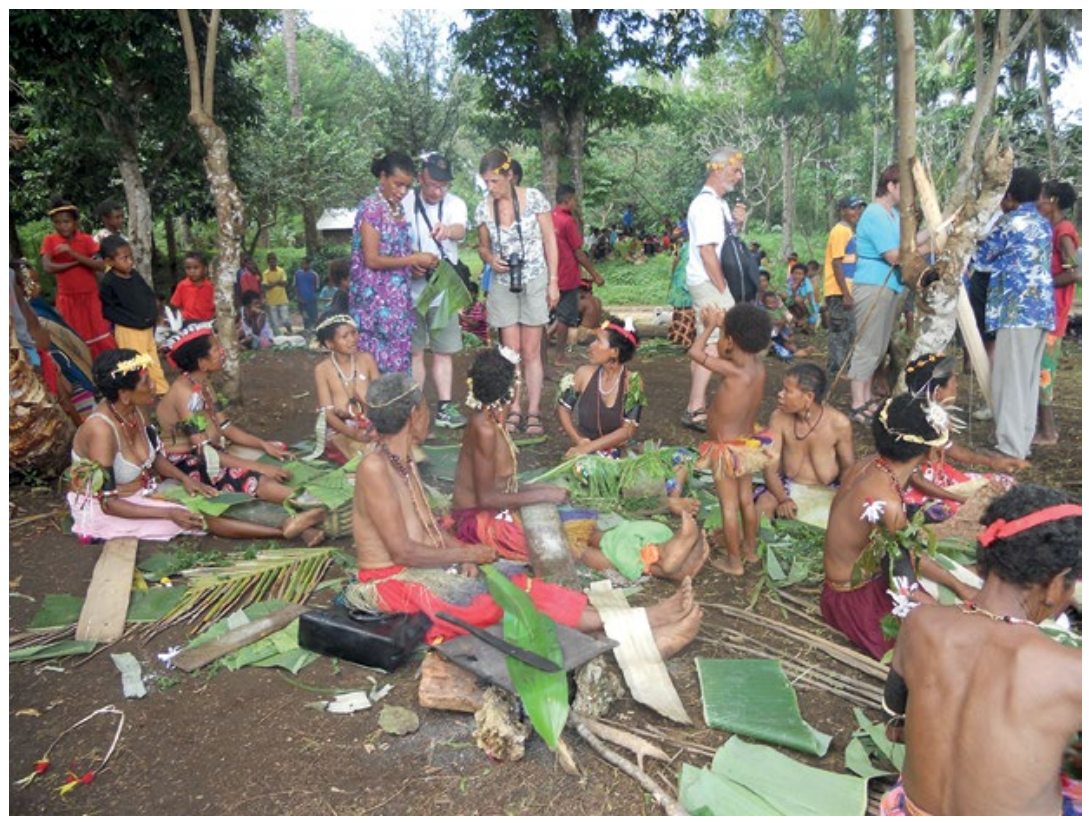

Figure 111. A group tour gets an 'up close' encounter with Trobriand villagers, Yalumgwa Village.

Source. Photographed by Michelle MacCarthy, 23 July 2013. 


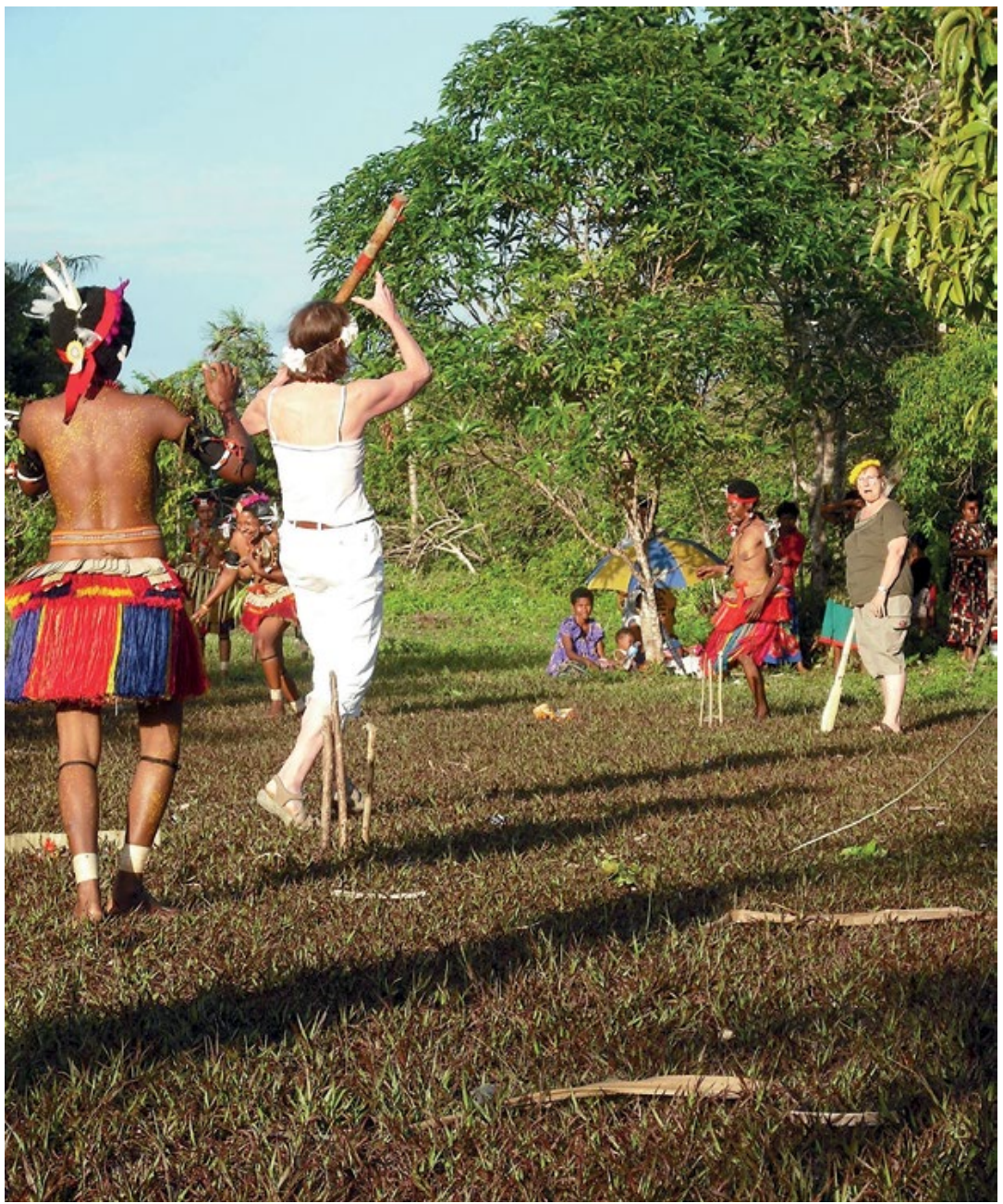

Figure 112. Visiting tourists participating in a Trobriand cricket match.

Source. Photographed by Michelle MacCarthy, 14 August 2009.

\section{Beyond the stage}

In several recent years, a small festival coinciding with the yam harvest period has been organised by Trobriand businesswoman Serah Clark, proprietor of Butia Lodge. The event, called Ugwabwena Festival, generates business for the lodge, often with invited guests representing mid- to high-level public servants and prominent businesspeople from 
the provincial capital of Alotau, the national capital Port Morseby, and other urban centres. It also attracts a small number of tourists. In 2009, a group of eight expatriate Australians living in Port Morseby and working for AusAID and other development projects came to Kiriwina for the festival. They opted to stay in a village rather than the guest lodge, and this was facilitated by a Trobriand Islander living in Port Moresby, with whom one of the expatriates, Max, had become acquainted. Kebs, their local host, had come back to the village from the city to coordinate and oversee their stay, including organising the construction of bush-materials huts in the local style to house the visitors. I interviewed most of this group, individually or several at a time, and these discussions clearly demonstrated the ways in which this idea of 'social distance' is perceived as significant to tourists' understandings of their experiences. The sentiments expressed by these visitors demonstrate the ways in which their interpretations of their experiences and their assessment of the authenticity of the place and its people were shaped by the 'closeness' they felt they had gained through their village stay.

The festival, of course, is organised in advance, with a number of formal speeches, a schedule of performances from each village and an emcee officiating over the events. A temporary shelter is erected to provide shade to invited guests and tourists, and plastic chairs are available for their comfort. The local audience (Trobrianders from the nearby villages come in droves) squats or sits on the periphery, with only a tree for shade if they are lucky. This demarcation is recognised as signifying a staged event, which made it, to many visitors, inherently inauthentic. For example, Amy said:

I think, to be honest, in terms of the festival itself, I'd like it to be a more organic experience, I didn't like ... the fact that there was a tent [the shaded seating area] ... I don't think that used to happen, I just want it to be real. If you [Trobrianders] get out there and you gyrate to the yam, I want to sit in the shade and watch you do that. In the shade of a tree, I don't need a chair. I can sit on the ground in the shade of a tree, just watching, and have it happen the way it would happen, and all these speeches, these long, tedious speeches, from all these random people is unnecessary. I'm sure it didn't happen like that in the old days. Just bring it back to that. ${ }^{26}$ 
The fact that the festival was taking place was identified by this group of Australians as a reason for the timing of the visit, but the interest in the Trobriands as a destination was generated through Max's acquaintance with Kebs, the general reputation of the Trobriand Islands within Papua New Guinea, ${ }^{27}$ and the quality of the word carvings that are produced for sale both in Kiriwina and in urban centres like Port Moresby. ${ }^{28}$ In addition to taking in some of the events of the organised festival, this group of visitors also undertook excursions from their host village to beaches and other villages, often with their local host as guide. All of these visitors agreed that staying in the village rather than the tourist lodge had given them a greater understanding of 'the culture'; as Max put it:

It would be so easy to come and stay in one of the lodges, and come and see the staged festival, and have zero interaction with the culture at all. Not saying that we've acculturated or anything, but we've scraped the surface, where it would be quite easy to come here for this weekend and not do that. ${ }^{29}$

The village experience was contrasted starkly with the staged nature of the Ugwabwena Festival, as they saw it. Peta expressed it thus:

It just sort of opens your eyes to a whole world of complexity, because you don't get answers in five days. [But it] does make you realise some of what's going on. The first day we arrived, too, there was a feast on for some of the aunties who - kind of a funeral feast ... So, they took us to see that, and we sat there for about half an hour being completely bamboozled. But that was so much more of the real culture, I guess, than what we've been seeing at the yam festival. ${ }^{30}$

Thus, for tourists, while the mode of exchange may not be conditioned by social distance - tourists still pay, in cash, for services renderedwe might paraphrase Sahlins to say that the span of social distance between those who exchange conditions the meaning of exchange,

27 The 'Islands of Love' trope is well-known throughout the country; see, for example, Katherine Lepani, 2012, Islands of Love, Islands of Risk: Culture and HIV in the Trobriands, Nashville, TN: Vanderbilt University Press; Michelle MacCarthy, 2013, “"More than grass skirts and feathers": Negotiating culture in the Trobriand Islands', International Journal of Heritage Studies 19(1): 62-77; Michelle MacCarthy, 2016, Making the Modern Primitive: Cultural Tourism in the Trobriand Islands, Honolulu: University of Hawai'i Press.

28 Sergio Jarillo de la Torre, 2013, 'Carving the spirits of the wood: An enquiry into Trobriand materialisations', PhD thesis, Department of Anthropology, University of Cambridge.

29 Interview with Max, Butia Lodge, Kiriwina Island, 11 July 2009.

30 Interview with Peta, Butia Lodge, Kiriwina Island, 11 July 2009. 
at least from the point of view of the visitor. ${ }^{31}$ Further, those experiences that do not involve cash payments, such as attending a funeral feast, may also be seen as 'closer' to 'real life' and thus more authentic. ${ }^{32}$ We also see here echoes of the frontstage/backstage dichotomy. ${ }^{33}$ A further ethnographic example reinforces the commonalities in these discourses, which are particularly uniform amongst the demographic of young, independent travellers I focus on here.

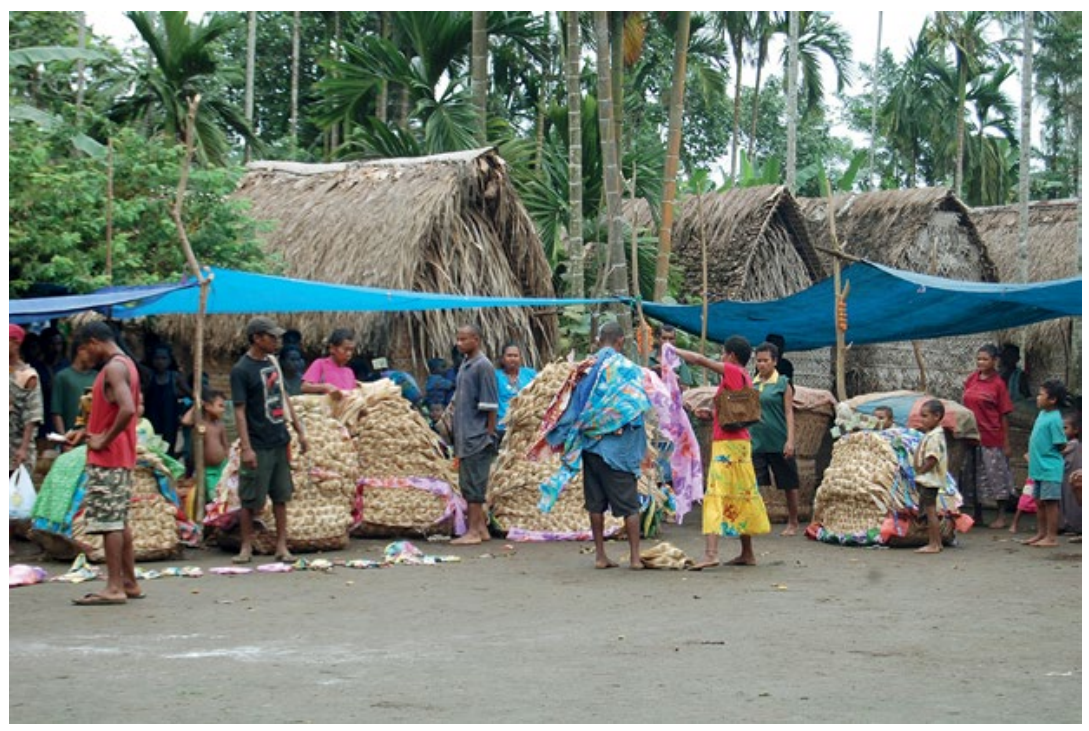

Figure 113. Attending a sagali (funeral feast) is a highlight for many cultural tourists to the Trobriands.

Source. Photographed by Michelle MacCarthy, 8 July 2010.

I met Simon, an independent English backpacker in his 30s, when he arrived at the small airstrip in Kiriwina on one of the (then) two weekly commercial flights from Port Moresby, via the provincial capital Alotau. Simon told me he had wanted to come to PNG and the Solomon Islands because he preferred 'off-the-beaten-track' destinations. He considered himself 'intrepid', having climbed PNG's

31 Sahlins, 'On the sociology of primitive exchange', p. 196.

32 For an in-depth discussion of the role of money in tourist transactions, see Michelle MacCarthy, 2015, “'Like playing a game where you don't know the rules": Investing meaning in intercultural cash transactions between tourists and Trobriand Islanders', Ethnos: Journal of Anthropology 80(4): 448-71.

33 Erving Goffman, 1971, The Presentation of Self in Everyday Life, Harmondsworth: Penguin; MacCannell, 'Staged authenticity'. 
highest peak, Mt Wilhelm, without a real guide, just a friend he had made while staying in a settlement in Goroka. He stayed in the settlement rather than in a hotel, because he 'met some nice people' who looked after him. His ability to make 'friends' and fit in was an important part of his narrative, and he felt it set him apart from mere 'tourists' and gave him a greater appreciation of life in the developing world. Like Tina and the group of Australians described above, he feels that staying with local people gives him the opportunity to interact and learn much more about how people live. In his estimation, Europeans have 'less culture' than people in places like the Pacific Islands. 'People in the West have lost sense their sense of community', he reckons; ${ }^{34}$ the 'simple life' of people living in the developing world held great romance.

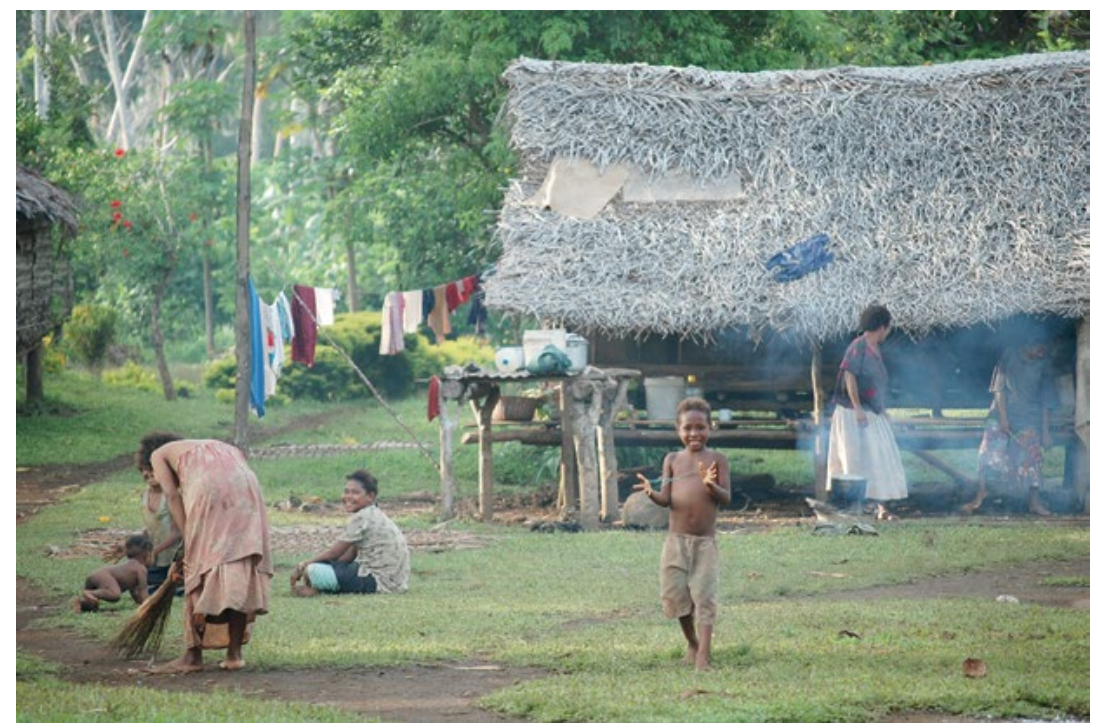

Figure 114. The 'simple life' of the village, as romanticised by visitors. Source. Photographed by Michelle MacCarthy, 10 December 2009.

These examples, while illuminating and offering a remarkable homogeneity in the ways in which cultural experiences are interpreted and understood by this particular tourist demographic, are not intended to suggest that all tourists agree on what is, and what isn't, 'authentic'. Nor do I suggest I have identified some unwavering law

34 Interview with Simon, Bweka hamlet, Kiriwina Island, 10 February 2010. 
or rule governing tourists' perceptions. Indeed, not all tourists see their experiences in the Trobriands as representing an authentic and unadulterated culture untainted by globalisation; I met several visitors who expressed their dismay at what they interpreted as a lack of authenticity. Some are disillusioned with what they see as the corrupting forces of modernity, and especially the scourge (as they see it) of missionisation. Christine, another of the Australian visitors who visited Kiriwina with her friends for Ugwabwena Festival, told me:

I have found the influence of missionaries disturbing, but that's nothing new. But, the fact that some of the locals were saying the other night when there was a Christian thing in our village that they, that they're taught, that their traditional god is evil and that they need to worship - that there's only one god, and they have to worship that one. Also that there used to be an island that they considered heaven ... But they're not allowed to think that anymore, that they've been told that that's wrong. And, uh, evil. ${ }^{35}$

Christine was not the only visitor who blamed the missionaries for adulterating what would otherwise (they thought) have been a pure and authentic way of life. Two visitors who had come on a small organised tour with a Port Moresby-based tour operator specialising in 'soft adventure experiences' ${ }^{36}$ undertook a village stay that they did not see as representing an authentic experience with authentically traditional people, as they had hoped. Olga, a Swiss woman in her 60s, told me that she and her companion had come to the Trobriands with a knowledge of what was in 'the old books' about traditional ways of life, and that she had thus arrived with the hope and expectation of seeing:

the old traditions. Really the old traditions. And everywhere we were told we don't do this anymore, we cannot talk about it [because of the missionaries]. Even background information, why is this and why is this - to really understand ... nothing could be fulfilled. So my expectations are totally - they hang out in an empty space, in an open empty space - nothing was fulfilled. Sorry to say, but that's the truth. ${ }^{37}$

35 Interview with Christine, Butia Lodge, 11 July 2009.

36 'Ecotourism Melanesia - Discover Papua New Guinea and Solomon Islands - Travel and Tourism Arrangements, Escorted Tours, Independent Touring, PNG Tourism Information, Accommodation and Sightseeing', 2016, Em.Com.Pg.

37 Interview with Olga, Kiriwina Lodge, 4 August 2009. 
Despite Olga's disappointment that she had not found a place frozen in time, where her essentialised ideas of authenticity could be satisfied, it is notable that staying in the village was the one positive thing she had to say in what was otherwise a lengthy tirade about the scourge of modernisation and missionisation. She conceded that amidst all of her failed expectations, staying in a village 'was nice, actually. It was actually a really nice feature, to live with the families ... Very warm-hearted, friendly, kind ... everything. ${ }^{38}$ Still, for Olga, it was not 'authentic' because it did not meet her preconceived ideas. While their responses to their experiences may have been different from most, visitors like Christine and Olga still demonstrate a concern with authenticity, and their disappointment might be interpreted as a reflection of failing to find the 'closeness' (in this case, to their own idealised expectations of essentialised 'traditional' people) they sought through an encounter with otherness.

\section{'When tourists come here, they don't want Disneyland'}

The general lack of tourism development and infrastructure in PNG is a feature that sets it apart from many other locations in which ethnotourism is promoted. The very absence of other tourists increases the sense of authenticity and the self-verification for tourists that one is, indeed, intrepid and has managed to 'get off the beaten track'. Many visitors commented positively on the lack of other tourists in the Trobriands, as tourists are blamed for having 'ruined' so many other destinations by their presence. In a telling comment that demonstrates the other side of the coin, an Australian visitor who arrived by private yacht on the same day that, coincidentally, a group of 16 North American visitors on an ElderTreks tour, an American expatriate working in Port Moresby, and two foreign journalists were also visiting the island, all of whom happened to converge in the northernmost village of Kaibola, observed that the island seemed 'like Disneyland' compared with the other small and relatively untouristed islands they had visited by yacht throughout Milne Bay Province. Too many tourists thus inauthenticate a place, make it a simulacra rather than the 'real thing', and rob the visitor of the experience of 
feeling truly intrepid. Disneyland represents, then, the antithesis of the authentic in which everything is fabrication. Interestingly, the same metaphor was used by Moshe, an elderly Israeli visitor staying at Butia Lodge with his wife, who observed, 'When tourists come here, they want to see that it is authentic. They don't want Disneyland.' ${ }^{39}$

Most people, however, find themselves the only tourists on the island when they visit, and this is itself a great attraction to tourists seeking an unspoiled place, and once again represents a sense of closeness with the place and its people than is available in destinations with heavy tourist traffic. The lack of other tourists and infrastructure validates a sense of difference from home, and a sense of getting a glimpse of 'real life'. Amy, one of the group of Australian expatriates introduced in the previous section, put it like this:

Here, it's like, they're really interested in you ... there's a curiosity about the tourists, as much as the tourists have a curiosity about the locals. I think there's still that sense of - alright, so there's not the infrastructure that's evident in other tourist locations, but that makes it real, you're still getting a feel for the people. If you're here even for a day, you'll still get a feel for how they live, what they do, their culture, which I think - which is my interest in tourism, and I appreciate [that]. ${ }^{40}$

Again, I want to stress that I do not make an argument that one kind of touristic experience is more or less authentic than another, in an empirical sense. That is not my concern. Instead, I seek to demonstrate that the ways in which visitors' perceptions of a place, a people, an event, or an object as authentically unique, unusual, or different from the known are directly related, for most cultural tourists, to the value they place on the experience. Like Tina, introduced at the beginning of this chapter, tourists to the Trobriand Islands consistently iterated the importance of feeling that their cultural interactions and touristic experiences were authentic and unusual as markers of their satisfaction with the experience. This 'feeling' is intuitive, and when prompted to explain how they know if a place/experience is authentic, many visitors found it hard to articulate, but yet were confident they knew it when they saw it.

39 Interview with Moshe, Butia Lodge, Kiriwina Island, 10 August 2010.

40 Interview with Amy, Butia Lodge, Kiriwina Island, 11 July 2009. 


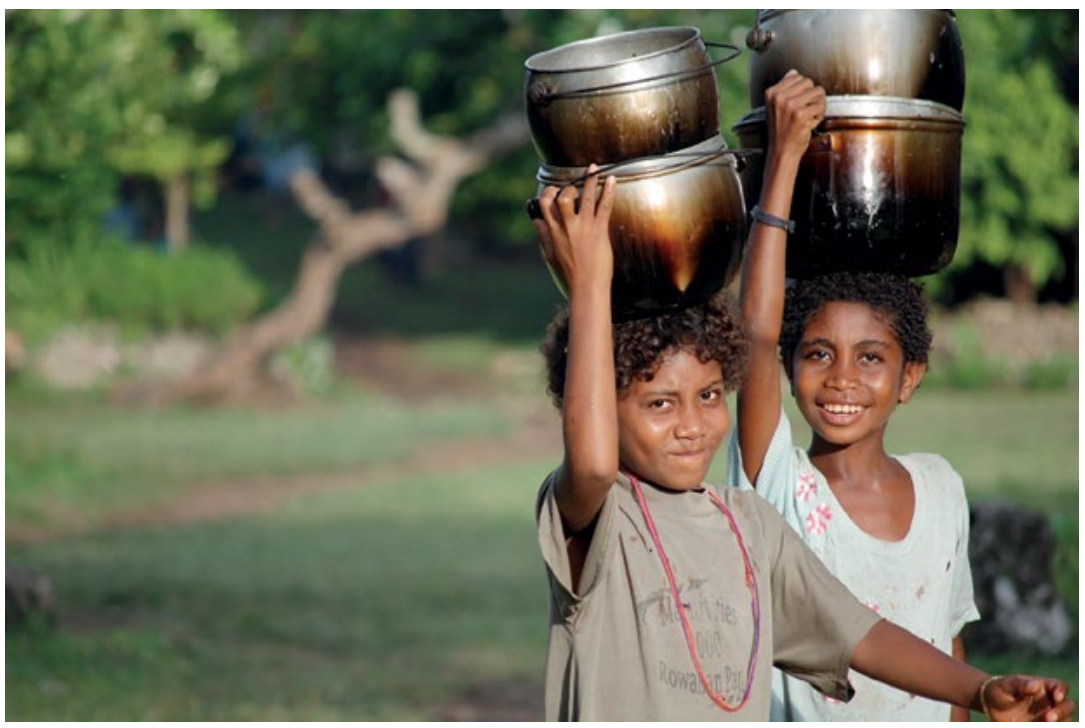

Figure 115. Young girls fetching water, Vakuta Island.

Source. Photographed by Michelle MacCarthy, 10 December 2009.

Herb, an American visitor in his 70s, was more explicit than most visitors about his desire for a singular and authentic cultural experience, and the emotive, intuitive nature of 'feeling' that a cultural experience is 'genuine':

These dances we see when we travel, sometimes they are authentic, but in some places they're clearly choreographed - here it appears to be genuine ... I don't know how you know, but there is a feeling, it seems natural, but that's just based on my own experience and interpretation. I'm not saying a put-up thing can't be good, it can be entertaining, but if it's not authentic, I won't enjoy it as much. I mean, if a singsing ${ }^{41}$ came to New York, it wouldn't really work - there'd be no drama to it. ${ }^{42}$

Regardless of whether visitors interpreted their experiences as authentic, unique, and singular or not, the point is that they are seeking such an experience, and value the opportunity to engage in a truly singular intercultural interaction.

41 Singsing is a PNG pidgin word referring to a cultural show, generally involving traditional dancers in their finery.

42 Interview with Herb, Butia Lodge, Kiriwina Island, 27 August 2010. 


\section{Conclusions: Commodifying experience}

In cultural tourism, this reified thingness conceived of as culturesometimes material (i.e. souvenirs, photographs) but more often intangible (performance, interactions with the other) is commodified; tourism is among the world's largest industries. Over a billion people today cross borders for business or leisure travel annually, ${ }^{43}$ and if current trends continue, this number could reach 1.8 billion by $2030 .^{44}$ Annual expenditures worldwide have since 2012 surpassed US\$1 trillion according to the United Nations World Tourism Organization. ${ }^{45}$

The quest for 'close' encounters, meaningful interactions with authentic representatives of otherness, is in many senses an attempt to imagine oneself outside the very infrastructure that makes tourism possible: outside the market, outside modernity, and outside relentless individualism.

Annette Weiner has made a case for some kinds of objects having more 'density' than others, by which she means that objects are cultural constructions that accrue symbolic importance through associations with their owner(s), histories and sacralisation, as well as aesthetic and economic values. ${ }^{46}$ I see the experience of a village stay in which the ideal of touring 'real life' - whether merely observed or, more significantly, participated in and experienced as embodied action - as not only 'close', but also symbolically dense for most tourists. For those whose desires are met by these experiences, they encapsulate evidence for the culture-seeking tourist of the existence of the authentic cultural other, and one's own ability to engage in an interaction conceived of as meaningful. Experience, then, may be a special kind of commodity, in which social distance and the expectations for reciprocity are manipulated, in a sense, often through active self-deception. Commodities are treated like gifts, objects and actions are invested with meaning beyond their physical properties,

\footnotetext{
43 UNWTO, 2014, UNWTO World Tourism Barometer, UNWTO.

44 UNWTO, 2014, UNWTO Tourism Highlights 2013 Edition, UNWTO.

45 Ibid.; UNWTO, UNWTO World Tourism Barometer.

46 Annette B. Weiner, 1994, 'Cultural difference and the density of objects', American Ethnologist 21(2): 391-403, p. 394.
} 
and strangers are treated as friends or even family. This inversion provides the perception, if not the reality, of experiencing the life of the cultural other 'as it is really lived'.

\section{References}

Alexeyeff, Kalissa. 2009. Dancing from the Heart: Movement, Gender, and Cook Islands Globalization. Honolulu: University of Hawai'i Press.

Bruner, Edward M. 1991. 'Transformation of self in tourism.' Annals of Tourism Research 18(2): 238-50.

- 1994. 'Abraham Lincoln as authentic reproduction: A critique of postmodernism.' American Anthropologist 96(2): 397-415.

Bruner, Edward M. (ed.). 2005. Culture on Tour: Ethnographies of Travel. Chicago: University of Chicago Press.

Cohen, Erik. 1988. 'Authenticity and commoditization in tourism.' Annals of Tourism Research 15(3): 371-86.

Condevaux, Aurélie. 2009. 'Māori culture on stage: Authenticity and identity in tourist interactions.' Anthropological Forum 19(2): 143-61.

Daniel, Yvonne Payne. 1996. 'Tourism dance performances: Authenticity and creativity.' Annals of Tourism Research 23(4): 780-97.

Dann, Graham M.S. (ed.). 2002. The Tourist as a Metaphor of the Social World. Wallingford, Oxon: CABI Publishing.

'Ecotourism Melanesia - Discover Papua New Guinea and Solomon Islands - Travel and Tourism Arrangements, Escorted Tours, Independent Touring, PNG Tourism Information, Accommodation and Sightseeing.' 2016. Em.Com.Pg. Online: www.em.com.pg/ (accessed 10 March 2016).

Goffman, Erving. 1971. The Presentation of Self in Everyday Life. Harmondsworth: Penguin. 
Graburn, Nelson H.H. (ed.). 1976. Ethnic and Tourist Arts: Cultural Expressions from the Fourth World. Berkeley: University of California Press.

_ 1984. 'The evolution of tourist arts.' Annals of Tourism Research 11(3): 393-419.

1999. 'Epilogue: Ethnic and tourist arts revisited.' In Unpacking Culture: Art and Commodity in the Colonial and Postcolonial Worlds, ed. Ruth B. Phillips and Christopher B. Steiner, pp. 335-54. Berkeley: University of California Press.

Hammons, Christian S. 2015. 'Shamanism, tourism, and secrecy: Revelation and concealment in Siberut, Western Indonesia.' Ethnos: Journal of Anthropology 80(4): 548-67.

Jamal, Tazim and Steve Hill. 2002. 'The home and the world: (Post) touristic spaces of (in)authenticity?' In The Tourist as a Metaphor of the Social World, ed. Graham M.S. Dann, pp. 77-108. Wallingford, Oxon: CABI Publishing.

Jarillo de la Torre, Sergio. 2013. 'Carving the spirits of the wood: An enquiry into Trobriand materialisations.' PhD thesis, Department of Anthropology, University of Cambridge.

Jones, Siân. 2010. 'Negotiating authentic objects and authentic selves.' Journal of Material Culture 15(2): 181-203.

Kaeppler, Adrienne. 1988. 'Pacific festivals and the promotion of identity, politics, and tourism.' In Come Mek Me Hol'Yu Han': The Impact of Tourism on Traditional Music, ed. Adrienne L. Kaeppler and Olive Lewin, pp. 12-38. Kingston, Jamaica: Jamaica Memory Bank.

Kaeppler, Adrienne L. and Olive Lewin (eds). 1988. Come Mek Me Hol'Yu Han': The Impact of Tourism on Traditional Music. Kingston, Jamaica: Jamaica Memory Bank.

Kirshenblatt-Gimblett, Barbara. 1998. Destination Culture: Tourism, Museums, and Heritage. Berkeley: University of California Press.

Lepani, Katherine. 2012. Islands of Love, Islands of Risk: Culture and HIV in the Trobriands. Nashville, TN: Vanderbilt University Press. 
Lockwood, Victoria S. (ed.). 2004. Globalization and Culture Change in the Pacific Islands. Upper Saddle River, NJ: Pearson Prentice Hall.

MacCannell, Dean. 1973. 'Staged authenticity: Arrangements of social space in tourist settings.' American Journal of Sociology 79(3): 589-603.

- 1976. The Tourist : A New Theory of the Leisure Class. New York Schocken Books.

MacCarthy, Michelle. 2012. "Before it gets spoiled by tourists": Constructing authenticity in the Trobriand Islands of Papua New Guinea.' PhD thesis, Department of Anthropology, University of Auckland.

—. 2013. "More than grass skirts and feathers": Negotiating culture in the Trobriand Islands.' International Journal of Heritage Studies 19(1): 62-77.

- 2015. "Like playing a game where you don't know the rules": Investing meaning in intercultural cash transactions between tourists and Trobriand Islanders.' Ethnos: Journal of Anthropology 80(4): 448-71.

- 2016. Making the Modern Primitive: Cultural Tourism in the Trobriand Islands. Honolulu: University of Hawai'i Press.

Olsen, Kjell. 2002. 'Authenticity as a concept in tourism research.' Tourist Studies 2(2): 159-82.

'Papua New Guinea - Adventure Travel For 50 Plus.' 2016. Eldertreks. Com. Online: www.eldertreks.com/tour/ETTD000355 (accessed 9 March 2016).

Peterson, Richard A. 2005. 'In search of authenticity.' Journal of Management Studies 42(5): 1083-098.

Phillips Ruth B. and Christopher B. Steiner (eds). 1999. 'Unpacking Culture: Art and Commodity in the Colonial and Postcolonial Worlds. Berkeley: University of California Press.

Sahlins, Marshal. 1972. 'On the sociology of primitive exchange.' In Stone Age Economics, ed. Marshall Sahlins, pp. 185-276. London: Tavistock. 
Schutte, Gerhard. 2003. "Tourists and tribes in the "new" South Africa.' Ethnohistory 50(3): 473-87.

Silverman, Eric Kline. 1999. 'Tourist art as the crafting of identity in the Sepik River (Papua New Guinea).' In Unpacking Culture: Art and Commodity in Colonial and Postcolonial Worlds, ed. Ruth B. Phillips and Christopher B. Steiner, pp. 51-66. Berkeley: University of California Press.

2004. 'Cannibalizing, commodifying, or creating culture? Power and art in Sepik River tourism.' In Globalization and Culture Change in the Pacific Islands, ed. Victoria S. Lockwood, pp. 339-57. Upper Saddle River, NJ: Pearson Prentice Hall.

Stanley, Nick. 1998. Being Ourselves for You: The Global Display of Cultures. London: Middlesex University Press.

Steiner, Christopher B. 1999. 'Authenticity, repetition, and the aesthetics of seriality: The work of tourist art in the age of mechanical reproduction.' In Unpacking Culture: Art and Commodity in Colonial and Postcolonial Worlds, ed. Ruth B. Phillips and Christopher B. Steiner, pp. 87-103. Berkeley: University of California Press.

Taylor, John. 2001. 'Authenticity and sincerity in tourism.' Annals of Tourism Research 28(1): 7-26.

UNWTO. 2014. UNWTO Tourism Highlights 2013 Edition. UNWTO. Online: www.e-unwto.org/content/hq4538/fulltext.pdf (accessed 25 February 2015).

- 2014. UNWTO World Tourism Barometer. UNWTO. Online: cf.cdn.unwto.org/sites/all/files/pdf/unwto_barom14_02_apr_ excerpt_0.pdf (accessed 25 February 2015).

Wang, Ning. 1999. 'Rethinking authenticity in tourism experience.' Annals of Tourism Research 26(2): 349-70.

Weiner, Annette B. 1994. 'Cultural difference and the density of objects.' American Ethnologist 21(2): 391-403. 
This text is taken from Touring Pacific Cultures, edited by Kalissa Alexeyeff and John Taylor, published 2016 by ANU Press, The Australian National University, Canberra, Australia. 